\title{
30 years of Virology Division News in Archives of Virology
}

\author{
Tim Skern ${ }^{1} \cdot$ Sead Sabanadzovic ${ }^{2}$
}

Received: 5 February 2021 / Accepted: 19 March 2021 / Published online: 9 April 2021

(c) The Author(s), under exclusive licence to Springer-Verlag GmbH Austria, part of Springer Nature 2021

2021 sees the $30^{\text {th }}$ anniversary of the collaboration between Springer (now SpringerNature), which publishes Archives of Virology (ARVI), and the Virology Division of the International Union of Microbiological Societies (VD-IUMS). This formal collaboration was heralded in an editorial written by the then journal Editor-in-Chief Dr. Frederick A. Murphy and published in the March 1991 issue of volume 116, announcing that ARVI had become the "Official Journal of the Virology Division of the International Union of Microbiological Societies". Moreover, a special section named "Virology Division News" (VDN) was to be established to promote "papers and proceedings of the International Committee on Taxonomy of Viruses (ICTV)" [1]. The inaugural article in this series was launched in the same volume and was authored by the first Section Editor Dr. Marian Horzinek. This paper presented the scope of the new section, with a vision that it should become "a platform for communicating many kinds of information of general interest to virologists around the world". A particular emphasis was to be placed on "coverage of taxonomic matters" [2], either formally by the ICTV or in the form of informal input from groups of virologists interested in that niche of virology. The section is managed by the VDN Section Editor, who is also a member of the ICTV Executive Committee (EC) [3]. Table 1 lists the VDN Section Editors and their years of service.

Despite being biased towards publishing advances in virus taxonomy, VDN articles have ranged in their content to include announcements for virology-focused meetings, technical meeting agendas, reports and obituaries. Updates on the Statutes of VD-IUMS and the ICTV, as well as changes in the International Code of Virus Taxonomy and

Sead Sabanadzovic

SSabanadzovic@entomology.msstate.edu

1 Max Perutz Labs, Medical University of Vienna, Vienna Biocenter, Dr. Bohr-Gasse 9/3, 1030 Vienna, Austria

2 Department of Biochemistry, Molecular Biology, Entomology and Plant Pathology, Mississippi State University, Mississippi State, MS 39762, USA
Nomenclature, have also been reported. A selection of published VDN articles on various topics is given in Table 2. All VDN articles from 1991 onwards are freely accessible at ARVI and can be found through the link on the journal web site (https://www.springer.com/journal/705).

Until the early 1990s, ICTV taxonomy updates were mostly communicated in the form of "Reports" published at irregular intervals, the most recent ICTV Report having appeared in 1982. This system of providing information, although comprehensive and complete, was cumbersome, difficult to prepare and distribute in a timely fashion, and did not allow for two-way communication. Hence, the ICTV, as a committee of VD-IUMS, fully embraced the opportunity provided by VDN to communicate important information to the worldwide community of virologists on a more frequent basis. Also, virologists with an interest in virus taxonomy, whether associated with the ICTV or not, saw the inception of VDN as an opportunity to provide feedback, express opinions on certain issues, and present informal taxonomic proposals for discussion and eventual consideration by the ICTV. As a result, VDN soon became a well-recognized platform for dialogue between the ICTV and virologists. In addition, over time, VDN articles became a public forum for lively exchanges of expert opinion on various issues concerning virus nomenclature and classification [4-7].

From its inception, VDN attracted a wide readership for its content and far-reaching impact. Indeed, many groundbreaking decisions and changes in virus taxonomy were originally announced in VDN articles. Early developments included, for example, the proposal to establish the first order of viruses, Mononegavirales, which was advanced by the "Paramyxovirus Study Group" of the Vertebrate Virus Subcommittee and published as the second VDN article [8]. It was soon followed by a paper announcing the proposal to recognize the first family of plant viruses, Potyviridae (at that time, plant virus taxonomy was still based on "virus groups" as taxonomic units) [9]. Finally, the decision to establish the species rank as the basic level of virus taxonomy was published in a VDN article reporting 
Table 1 List of Virology Division News Editors since 1991

\begin{tabular}{ll}
\hline Marian C. Horzinek & $1991-1996$ \\
Craig R. Pringle & $1996-1999$ \\
Michael A. Mayo & $1999-2005$ \\
Anne-Lise Haenni & $2005-2011$ \\
Jens H. Kuhn & $2011-2017$ \\
Sead Sabanadzovic & 2017 - date \\
\hline
\end{tabular}

the outcomes of the $20^{\text {th }}$ meeting of the EC held in Atlanta, GA in April 1991 [10]. This initial year of VDN concluded with a paper recommending the definition of the virus species as a "polythetic class of viruses", which was soon adopted by the ICTV [11]. Looking back, it is clear that VDN rapidly jump-started vigorous debates in many areas of virology and has played a vital role in viral taxonomy and classification.

Over the past 30 years, VDN has kept its relevance among virologists as a reference for reliable virus taxonomy-related information provided in a timely fashion by the ICTV. Of particular interest to the community are the annual updates authored by the entire EC reporting the changes approved by the ICTV at the ratification vote. Recently, these articles have also explained some strategic changes in ICTV practices and standards, such as the acceptance of metagenomic-derived sequence data for virus classification, the introduction of a 15-rank taxonomic system, and the establishment of the first virus realm (Riboviria) [12-17]. One recent proposal from a number of EC members to introduce standardized binomial names promoted much discussion in the community, as it would have meant wide-ranging changes to the names of species [18]. After discussion and deliberation during the $52^{\text {nd }}$ annual EC meeting held in a virtual format in October 2020, the final decision on this important topic will be made at the ratification vote scheduled for the first trimester of 2021. We note that elections to the EC have recently taken place and wish the newly elected and re-elected members a successful period of office, as well as the energy to steer the ICTV through the current period of virological change.

With this article, Sead Sabanadzovic as the Section Editor of VDN and Tim Skern as the Editor-in-Chief of ARVI would like to stress the importance of discussions on topics of interest for virologists that arise from issues of virus taxonomy and nomenclature. The $290 \mathrm{VDN}$ articles that have been published over the past 30 years are now freely accessible and thus available to all. We earnestly hope that the virology community will continue to take the opportunity provided through VDN to conduct constructive scientific debates and engage in dialogue with the ICTV. We look forward to receiving and reading many such articles in the future.

Table 2 A selection of Virology Division News articles in Archives of Virology

\begin{tabular}{|c|c|c|c|c|}
\hline Volume & Year & Pages & Author(s) & Title \\
\hline 118 & 1991 & $139-141$ & OW Barnett & Potyviridae, a proposed family of plant viruses. \\
\hline 140 & 1995 & $1515-1520$ & J Maniloff & Identification and classification of viruses that have not been propagated. \\
\hline 140 & 1995 & $1871-1884$ & H-W Ackermann et al. & Relationships of tailed phages: a survey of protein sequence identity. \\
\hline 142 & 1997 & $629-633$ & D Cavanagh & Nidovirales: a new order comprising Coronaviridae and Arteriviridae \\
\hline 142 & 1997 & $2321-2326$ & CR Pringle & The order Mononegavirales - current status. \\
\hline 142 & 1997 & $2553-2562$ & M Padidam et al. & A proposal for naming geminiviruses. \\
\hline 142 & 1997 & $1734-1739$ & C Buechen-Osmond & Further progress in ICTVdB, a universal virus database. \\
\hline 143 & 1998 & $421-424$ & EP Rybicki & $\begin{array}{l}\text { A proposal for naming geminiviruses: a reply by the Geminiviridae Study Group } \\
\text { Chair. }\end{array}$ \\
\hline 147 & 2002 & $2251-2253$ & J Dijkstra and JA Khan & The current naming of plant viruses: a critical appraisal \\
\hline 145 & 2000 & $1505-1507$ & AJ Gibbs & Virus nomenclature descending into chaos \\
\hline 159 & 2014 & 2189-21919 & CH Calisher \& RB Tesh & Two misleading words in reports of virus discovery: little things mean a lot \\
\hline 162 & 2017 & $1441-1446$ & MJ Adams et al. & $\begin{array}{l}50 \text { years of the International Committee on Taxonomy of Viruses: progress and } \\
\text { prospects }\end{array}$ \\
\hline
\end{tabular}


Acknowledgements We thank Tanja Grabner for support in data mining, and former and current ICTV Presidents, Andrew J. Davison and F. Murilo Zerbini, for critical reading of the manuscript.

\section{References}

1. Murphy FA (1991) Editorial. Arch Virol 116:i

2. Horzinek MC (1991) Editorial. Arch Virol 116:293-294

3. Mayo MA, Van Regenmortel MHV (2000) ICTV and virology division news. Arch Virol 145:1985-1988

4. Bos L (1999) The naming of viruses: an urgent call to order. Arch Virol 144:631-636

5. Van Regenmortel MHV, Mayo MA, Fauquet CM, Maniloff J (2000) Virus nomenclature: consensus versus chaos. Arch Virol $145: 2227-2232$

6. Agut H (2002) Back to Latin and tradition: a proposal for an official nomenclature of virus species. Arch Virol 147:1465-1470

7. Gibbs AJ (2003) Viral nomenclature, where next. Arch Virol 148:1645-1653

8. Pringle CR, Alexander DJ, Billeter MA, Collins PL, Kingsbury DW, Lipkind MA, Nagai Y, Orvell C, Rima B, Rott R, ter Meulen V (1991) The order Mononegavirales. Arch Virol 117:137-140

9. Barnett OW (1991) Potyivirdae. A proposed family of plant viruses. Arch Virol 118:139-141

10. Pringle CR (1991) The 20th meeting of the executive committee of the international committee on virus taxonomy. Arch Virol 119:303-304

11. Van Regenmortel MHV, Maniloff J, Calisher C (1991) The concept of virus species. Arch Virol 120:313-317

12. Adams MJ, Lefkowitz EJ, King AMQ, Harrach B, Harrison RL, Knowles NJ, Kropinski AM, Krupovic M, Kuhn JH, Mushegian AR, Nibert M, Sabanadzovic S, Sanfaçon H, Siddell SG, Simmonds P, Varsani A, Zerbini FM, Gorbalenya AE, Davison AJ (2017) Changes to taxonomy and the International Code of Virus Classification and Nomenclature ratified by the International Committee on Taxonomy of Viruses (2017). Arch Virol 162:2505-2538

13. King AMQ, Lefkowitz EJ, Mushegian AR, Adams MJ, Dutilh BE, Gorbalenya AE, Harrach B, Harrison RL, Junglen S, Knowles NJ, Kropinski AM, Krupovic M, Kuhn JH, Nibert ML, Rubino L,
Sabanadzovic S, Sanfaçon H, Siddell SG, Simmonds P, Varsani A, Zerbini FM, Davison AJ (2018) Changes to taxonomy and the International Code of Virus Classification and Nomenclature ratified by the International Committee on Taxonomy of Viruses (2018). Arch Virol 163:2601-2631

14. Siddell SG, Walker PJ, Lefkowitz EJ, Mushegian AR, Adams MJ, Dutilh BE, Gorbalenya AE, Harrach B, Harrison RL, Junglen S, Knowles NJ, Kropinski AM, Krupovic M, Kuhn JH, Nibert M, Rubino L, Sabanadzovic S, Sanfaçon H, Simmonds P, Varsani A, Zerbini FM, Davison AJ (2019) Additional changes to taxonomy ratified in a special vote by the International Committee on Taxonomy of Viruses (October 2018). Arch Virol 164:943-946

15. Gorbalenya AE (2018) Increasing the number of available ranks in virus taxonomy from five to ten and adopting the Baltimore classes as taxa at the basal rank. Arch Virol 163:2933-2936

16. Walker PJ, Siddell SG, Lefkowitz EJ, Mushegian AR, Dempsey DM, Dutilh BE, Harrach B, Harrison RL, Hendrickson RC, Junglen S, Knowles NJ, Kropinski AM, Krupovic M, Kuhn JH, Nibert M, Rubino L, Sabanadzovic S, Simmonds P, Varsani A, Zerbini FM, Davison AJ (2019) Changes to virus taxonomy and the International Code of Virus Classification and Nomenclature ratified by the International Committee on Taxonomy of Viruses (2019). Arch Virol 164:2417-2429

17. Walker PJ, Siddell SG, Lefkowitz EJ, Mushegian AR, Adriaenssens EM, Dempsey DM, Dutilh BE, Harrach B, Harrison RL, Hendrickson RC, Junglen S, Knowles NJ, Kropinski AM, Krupovic M, Kuhn JH, Nibert M, Orton RJ, Rubino L, Sabanadzovic S, Simmonds P, Smith DB, Varsani A, Zerbini FM, Davison AJ (2020) Changes to virus taxonomy and the Statutes ratified by the International Committee on Taxonomy of Viruses (2020). Arch Virol 165:2737-2748

18. Siddell SG, Walker PJ, Lefkowitz EJ, Mushegian AR, Dutilh BE, Harrach B, Harrison RL, Junglen S, Knowles NJ, Kropinski AM, Krupovic M, Kuhn JH, Nibert ML, Rubino L, Sabanadzovic S, Simmonds P, Varsani A, Zerbini FM, Davison AJ (2020) Binomial nomenclature for virus species: a consultation. Arch Virol 165:519-525

Publisher's Note Springer Nature remains neutral with regard to jurisdictional claims in published maps and institutional affiliations. 